\title{
Études/Inuit/Studies
}

\section{Thèses / Dissertations}

Volume 27, numéro 1-2, 2003

Architecture paléoesquimaude

Palaeoeskimo Architecture

URI : https://id.erudit.org/iderudit/010829ar

DOI : https://doi.org/10.7202/010829ar

Aller au sommaire du numéro

Éditeur(s)

Association Inuksiutiit Katimajiit Inc.

ISSN

0701-1008 (imprimé)

1708-5268 (numérique)

Découvrir la revue

Citer ce document

(2003). Thèses / Dissertations. Études/Inuit/Studies, 27(1-2), 561-568.

https://doi.org/10.7202/010829ar d'utilisation que vous pouvez consulter en ligne.

https://apropos.erudit.org/fr/usagers/politique-dutilisation/ 


\section{Thèses / Dissertations}

\section{BEHRISCH, Erika Kathryn Renee}

2002 Voices of silence, texts of truth: Imperial discourse and cultural negotiations in nineteenth-century British Arctic exploration narrative, Ph.D., Queen's University, Kingston, Ontario, 211 p.

Despite recent scholarship on the ubiquity of Arctic images within 19th century British culture, British Arctic exploration as an imperial enterprise has not been adequately analysed. Using Edward Said's examination of imperial discourses as a critical foundation, I treat 19th century Arctic exploration narrative as an imperialist project, arguing that its affiliated "dialects" of science and religion run parallel to Britain's dialects in other, more recognized parts of the empire. Analysing the effectiveness of British imperial discourse to contain explorers' experiences in the Arctic, however, I argue that the discursive obligations placed on explorers to reconcile their northern experiences with a domestically-generated heroic ideal produced texts that were radically ambivalent. Because they were restricted in their representations of exploration, explorers were unable to account fully for their experiences in the North, and were forced to rely on Natives - and particularly Inuit - voices for both subject matter and narrative drive. This thesis identifies two distinct phases in Arctic exploration discourse - 1818-1853 and 1854-1860 - the division between the two being the British reception of the 1854 Inuit testimony regarding the lost Franklin expedition, which, according to Inuit, succumbed to cannibalism before perishing. Within the first phase of Arctic exploration, writing remains ambivalent as it negotiates between expressing imperial enthusiasm for the project and presenting a realistic picture of explorers' Arctic experiences. The frequent textual inclusions of Native knowledge highlight explorers' dependence on Natives for aid and information, implying that British Arctic exploration could not have been effected without them. In contrast, the second phase of Arctic exploration discourse is homogeneous in its outright rejection of Native information, prompted by the Inuit cannibal testimony. Recognized as being able to undermine the British imperial narrative, Native testimony is firmly marginalized in favour of presenting the Arctic explorer as an overtly mythic construct, but one who remains physically and culturally independent.

$\square \quad$ Le discours impérialiste et les négociations culturelles dans les récits d'exploration britannique de l'Arctique au $19 e$ siècle, Ph.D., Queen's University, Kingston, Ontario, 211 p.

Malgré de récentes études sur les images de l'Arctique dans la culture britannique du 19 e siècle, l'exploration de cette région n'a pas été adéquatement analysée en tant qu'entreprise impérialiste. En utilisant les écrits d'Edward Said, j'analyse les récits de cette exploration comme faisant partie d'un tel projet et identifie ses "dialectes" affiliés 
en science et en religion qui sont des aspects mieux connus de l'empire britannique. En étudiant l'aptitude du discours impérial britannique à incorporer les expériences des explorateurs dans l'Arctique, je démontre que l'obligation de réconcilier leurs expériences nordiques avec un idéal héroïque britannique a produit des textes très ambivalents. Puisqu'ils étaient restreints dans leurs représentations de l'exploration, les explorateurs étaient incapables de décrire pleinement leurs expériences nordiques, et ainsi forcés de donner la parole aux Autochtones - particulièrement aux Inuit - pour les sujets à aborder. Cette thèse identifie deux phases distinctes dans le discours de l'exploration arctique - 1818-1853 et 1854-1860 - la division entre les deux étant la réception britannique en 1854 du témoignage des Inuit concernant la disparition de l'équipage de Franklin qui selon eux succomba au cannibalisme avant de périr. Pendant la première phase de l'exploration arctique, l'écriture reste ambivalente et doit négocier entre l'enthousiasme impérialiste pour l'exploration et la présentation d'une image réaliste des expériences arctiques des explorateurs. L'inclusion fréquente de textes concernant les savoirs autochtones met l'emphase sur la dépendance des explorateurs face à l'aide et à l'information des Autochtones, ce qui implique que les explorations britanniques de l'Arctique n'auraient pu être réalisées sans eux. Par contraste, la deuxième phase du discours est homogène dans son rejet complet d'informations provenant des Autochtones, suite au témoignage des Inuit concernant le cannibalisme. Identifié comme étant capable de saper le récit impérial britannique, le témoignage autochtone est fermement marginalisé en faveur d'une construction mythique de l'explorateur arctique qui reste physiquement et culturellement indépendant.

\section{HAYES, Michael Geoffrey}

2002 Paleogenetic assessments of human migration and population replacement in North American Arctic prehistory, Ph.D., University of Utah, Salt Lake City, 139 p.

Archaeological detection of population replacements over large regions in the prehistoric record is difficult given that culture can be geographically transmitted in the absence of wholesale population movements. The development of methodologies to analyze DNA from human remains several thousand years old affords a direct examination of genetic relationships between pre- and post-transition populations. Three to five mitochondrial DNA restriction sites and one length polymorphism were typed in pre-transition Paleo-Eskimos and post-transition Neo-Eskimos from the eastern North American Arctic. Frequency comparisons of the haplogroups these markers define yielded significant differences between the two groups. Combined with radiocarbon dates of each skeletal sample examined genetically, this indicates the archaeologically defined Paleo- to Neo-Eskimo transition represents a true population replacement. Stable carbon and nitrogen isotope analyses suggest the transition was accompanied by a change in foraging strategies from reliance on sealing to open-sea hunting of bowhead whale. Similar genetic and radiocarbon examinations of the craniometrically defined pre-transition Paleo-Aleuts and post-transition Neo-Aleuts in the western North American Arctic yielded haplogroup frequencies that are statistically 
indistinguishable from each other and from the contemporary Aleut population. This indicates a long, continuous, single human occupation of the Aleutian Islands.

Estimations paléogénetiques de migrations humaines et de remplacements de populations dans la préhistoire de l'Arctique nord-américain, Ph.D., University of Utah, Salt Lake City, 139 p.

La détection archéologique des remplacements de populations à travers de vastes régions durant la préhistoire est difficile à démontrer puisque la culture peut se transmettre géographiquement en l'absence de mouvements de populations. Le développement de méthodes analysant l'ADN des restes humains de quelques milliers d'années a permis l'étude des relations génétiques entre des populations pré- et posttransitionnelles. Trois des cinq sites de restriction des mitochondries de l'ADN et une longueur de polymorphisme ont identifié les Paléoesquimaux de pré-transition et les Néoesquimaux de post-transition dans l'Arctique de l'Amérique du Nord orientale. Les comparaisons de la fréquence des haplogroupes que ces marqueurs définissent ont montré des différences importantes entre les deux groupes. Ces résultats combinés aux datations au radiocarbone de chacun des échantillons de squelettes examinés génétiquement indiquent que la transition paléo- à néo-esquimaude définie archéologiquement représente un réel remplacement de population. Les analyses du carbone stable et de l'isotope de l'azote suggèrent que la transition fut accompagnées par un changement dans les stratégies de subsistance; soit d'une dépendance à la chasse au phoque par celle de la chasse à la baleine boréale. Des études génétiques et du radiocarbone similaires faites sur les populations paléo-aléoutes de pré-transition et celles néo-aléoutes de post-transition de l'ouest de l'Amérique du Nord définies par la craniométrie démontrent que les fréquences des haplogroupes sont indiscernables statistiquement pour ces populations entre elles et avec la population aléoute contemporaine. Cela indique une occupation humaine continue depuis fort longtemps dans les îles Aléoutiennes.

\section{LARSEN, Joan Nymand}

2002 Economic development in Greenland: A time series analysis of dependency, growth, and instability, Ph.D., University of Manitoba, Winnipeg, 348 p.

The main objective of this thesis is an empirical investigation into obstacles to economic development in Greenland. A central theme is the degree of trade, financial, and technological dependency, and its consequences for economic growth and instability in Greenland's post-colonial history. Econometric models are specified to test hypotheses about the association between economic dependency and growth and instability. The econometric results suggest first, that primary exports have been able to produce trickle-down effects that have been a contributing factor in the economic growth process in Greenland. Second, the results of an empirical investigation into the relationship between economic growth in Greenland and indicators of trade, financial, and technological dependency do not find support for the theoretical proposition that a 
negative association exists between economic growth and dependency. Rather, the evidence points to a positive association between growth and some indicators of dependency. Third, an analysis of structural change and instability suggests that structural change has occurred in Greenland. In general, the analysis points to the sensitivity of the Greenland economy to shocks to its natural resource supply, and it highlights the lack of a real change in policy regime with the implementation of Home Rule. Fourth, an empirical investigation into the degree of export and income instability in Greenland, and its causes and consequences, suggests first, that export and income instability is associated with some indicators of economic dependency, and second, that they both act as deterrents to economic growth in Greenland.

$\square \quad$ Le développement économique au Groenland: analyse de la dépendance, de la croissance et de l'instabilité, Ph.D., University of Manitoba, Winnipeg, 348 p.

L'objectif principal de cette thèse est une recherche empirique des obstacles au développement économique du Groenland. Le thème central est le degré de dépendance commerciale, financière et technologique et ses conséquences dans la croissance économique et l'instabilité du Groenland dans son histoire post-coloniale. Des modèles économiques sont utilisés afin de vérifier des hypothèses concernant les liens entre la dépendance économique, la croissance et l'instabilité. Les résultats économétriques suggèrent que premièrement, les exportations primaires ont produit une croissance économique au Groenland. Deuxièmement, les résultats d'une enquête empirique des relations entre la croissance économique du Groenland et les indicateurs de la dépendance commerciale, financière, et technologique ne confirment pas la théorie qu'il existe une association négative entre la croissance économique et la dépendance. Les données démontrent plutôt une association positive entre la croissance et certains indicateurs de dépendance. Troisièmement, une analyse du changement structurel et de l'instabilité suggère qu'un changement structurel s'est produit au Groenland. En général, l'analyse montre la sensibilité de l'économie groenlandaise aux chocs affectant son approvisionnement en ressources naturelles, et souligne le manque de changement réel dans le régime politique depuis la mise en oeuvre de l'autonomie interne. Quatrièmement, une enquête empirique sur le volume des exportations et la stabilité du revenu au Groenland, ainsi que leurs causes et conséquences, suggère premièrement que les exportations et l'instabilité du revenu sont associées à quelques indicateurs de dépendance économique, et deuxièmement, qu'elles nuisent à la croissance économique du Groenland.

STECKLEY, John Lawson

2003 Aboriginal voices and the politics of representation in Canadian introductory sociology textbooks, Ed.D., University of Toronto, Ontario, $243 \mathrm{p}$.

In this study, 77 Canadian introductory sociology textbooks ranging in date from 1961 to 2002 are analysed for the way that they present Aboriginal peoples. This 
analysis is informed by critical theorists such as Michel Foucault, Dorothy Smith, Jean Baudrillard and Linda Tuhiwai Smith, as well as by the writings of a good number of Aboriginal writers. In the thesis, special focus is placed on three subjects: the sociological myth of culturally determined Inuit elder suicide; the potlatch; and the 1990 Oka confrontation. In this work, it is argued that as the discipline of sociology developed in Canada, the writers / editors of these introductory sociology textbooks denied Aboriginal voice in the production of knowledge in these texts. In so doing, they portrayed Aboriginal peoples in limited, often distorted ways.

Les voix autochtones et les politiques de la représentation dans les textes canadiens d'introduction à la sociologie, Ed.D., University of Toronto, Ontario, 243 p.

Dans cette étude, 77 textes canadiens d'introduction à la sociologie datant de 1961 à 2002 sont analysés par rapport à leur façon de présenter les peuples autochtones. Cette analyse utilise les écrits de théoriciens tels que Michel Foucault, Dorothy Smith, Jean Baudrillard et Linda Tuhiwai Smith, ainsi que ceux d'un bon nombre d'auteurs autochtones. Trois sujets sont spécifiquement étudiés: le mythe sociologique du suicide culturellement déterminé des aînés inuit, le potlatch, et la confrontation de 1990 à Oka. Cette étude soutient qu'alors que la sociologie se développait comme discipline au Canada, les auteurs et rédacteurs de ces textes d'introduction à la sociologie ont nié la voix autochtone dans la production du savoir. Ce faisant, ils ont produit un portrait limité et déformé des peuples autochtones.

\section{VINKOVETSKY, Ilya}

2002 Native Americans and the Russian Empire, 1804-1867 (Alaska), Ph.D., University of California, Berkeley, $422 \mathrm{p}$.

In a broader sense, this dissertation presents a case study in the practice of Russian colonialism. More strictly defined, it is about how the Russians attempted to change the cultures of indigenous peoples of their colony in North America (encompassing the Aleutian Islands, Alaska, and California) in order to make them conform to the image of loyal subjects of the Russian Empire. To analyze this process, I divide the initiatives of the Russians intended to influence the Native Americans into three broad categories: pacification, christianization, and russianization. These categories are heuristic devices that help illuminate the connections between, on the one hand, imposed and mediated cultural change and, on the other, such features as Russian America's peculiar labour structure in particular and the imperatives of the fur trade in general. This study commences in 1804, because it was during that year that one of the two ships of the first Russian round-the-world voyage reached Russian America, and ends in 1867, the year that Alaska is transferred from the Russian Empire to the United States. The opening chapter discusses the goals, structure, and function of the Russian-American Company as a business venture, an imperial factor, and a colonial enterprise. It also introduces the indigenous peoples of the region and outlines their responses to being 
drawn into Russia's sphere of influence. Chapter Two analyzes how the initiation of round-the-world voyages - from the Baltic to the North Pacific via the Southern Hemisphere - changed the practice of Russian colonization in North America. Particular emphasis is placed on the transformational effect of these voyages on the representations of the colony's indigenous peoples. Chapters Three and Four focus on the motives and designs of the Russians to pacify the Native Americans. Chapter Five addresses how Russian colonial officials tried to reshape indigenous identities through russianization. The last chapter deals with how the Russians employed Orthodox Christianity to buttress both pacification and russianization.

- Les Autochtones américains et l'empire russe, 1804-1867 (Alaska), Ph.D., University of California, Berkeley, $422 \mathrm{p}$.

Dans un sens large, cette thèse présente une étude sur la pratique du colonialisme russe. Mais d'une façon plus définie, il s'agit de comprendre comment les Russes essayèrent de changer les cultures des peuples autochtones dans leur colonie de l'Amérique du Nord (incluant les îles Aléoutiennes, l'Alaska et la Californie) afin de les conformer à l'image de sujets loyaux de l'empire russe. Pour analyser ce processus, je divise en trois catégories les initiatives que les Russes utilisèrent afin d'influencer les Autochtones américains: la pacification, la christianisation, et la russification. Ces catégories sont des moyens heuristiques qui aident à illuminer les connections entre, d'un côté, les changements culturels imposés et négociés, et de l'autre, certains aménagements comme la structure particulière du travail en Russie américaine et les impératifs de la traite des fourrures en général. L'étude commence en 1804, l'année où l'un des deux premiers bateaux russes voyageant autour du monde arriva en Amérique, et se termine en 1867, l'année où l'Alaska fut transférée de l'empire russe aux ÉtatsUnis. Le chapitre 1 discute des buts, de la structure et de la fonction de la RussianAmerican Company comme une entreprise risquée, un facteur impérialiste et une aventure coloniale. Il présente aussi les peuples autochtones de la région et décrit leurs réponses à cette inclusion dans la sphère d'influence de la Russie. Le chapitre 2 analyse comment ces premiers voyages autour du monde changèrent la façon dont se fit la colonisation russe en Amérique du Nord. Une emphase particulière est mise sur l'effet de transformation qu'eurent ces voyages sur les représentations des peuples autochtones de la colonie. Les chapitres 3 et 4 se penchent sur les motifs et méthodes des Russes pour pacifier les Autochtones américains. Le chapitre 5 montre comment les fonctionnaires russes essayèrent de transformer les identités autochtones en les russifiant. Le dernier chapitre traite de la façon dont les Russes employèrent le christianisme orthodoxe dans la pacification et la russification. 
WOOLLETT, James Malcolm

2003 An historical ecology of Labrador Inuit culture change, Ph.D., City University of New York, 698 p.

This dissertation reports the results of an historical ecology-oriented archaeological investigation of Labrador Inuit culture change during the contact period. The research provides the first detailed description of Labrador Inuit subsistence economies based on a regional-scale analysis of faunal remains. It also draws together archaeobotanical, palaeoentomological and palaeoenvironmental research and also ethnohistorical data, in order to define changes in the Inuit subsistence economy and their relationships to larger environmental and culture changes. This range of data sets and approaches are used to construct a landscape history for Labrador, linking complex climatic and ecological variables with historically situated agents and their economic activities. In particular, the study examines the use of communal winter residences by the Labrador Inuit during the 18th century, a culture change that has been linked to environmental deterioration and economic stress during the Little Ice Age and, alternatively, to the social action of aggrandizers with circumstances of economic security and culture contact. These theories are tested with a variety of subsistence data that focus on the seasonality, diversity and productivity of Inuit hunting practices demonstrated in several well-dated faunal assemblages and on the roles of strategies of surplus production and stress management in economic decision-making. As well, a variety of high-resolution palaeoenvironmental records are used to determine the direction of environmental change and how it influenced economic opportunities. The study suggests that the Labrador Inuit enjoyed a degree of economic security and success in the 18th century, aided in part by an interlude of moderated climatic and sea ice conditions. These conditions encouraged the use of cooperative sea mammal hunting methods, which were reinforced by the use of communal residences. This economy facilitated surplus-producing and risk-taking economic strategies and a more prominent social role for aggrandizers.

Une écologie historique des changements culturels des Inuit du Labrador, Ph.D., City University of New York, 698 p.

Cette thèse concerne les résultats d'une étude archéologique orientée par l'écologie historique des changements culturels des Inuit du Labrador durant la période de contact. Cette recherche présente la première description détaillée des économies de subsistance des Inuit du Labrador se basant sur une analyse régionale des vestiges fauniques. On y intègre aussi des études archéobotaniques, paléoentomologiques et paléoenvironnementales ainsi que des données ethnohistoriques afin de définir les changements dans l'économie de subsistance des Inuit et leurs relations à des changements environnementaux et culturels plus vastes. Ces données sont utilisées pour construire une histoire du paysage du Labrador liant des variables complexes concernant le climat et l'écologie avec des agents historiques et leurs activités économiques. L'étude examine en particulier l'utilisation de résidences d'hiver communautaires par les Inuit du Labrador durant le 18e siècle, un changement culturel qui a été lié à une détérioration environnementale et un stress économique durant le 
Petit Âge Glaciaire et, alternativement, à la sécurité économique et au contact culturel. Ces théories sont testées avec une variété de données relatives à la subsistance mettant l'emphase sur la saisonnalité, diversité et productivité des pratiques de chasse inuit et sur le rôle des stratégies de production de surplus et la gestion du stress dans les décisions économiques. De plus, une variété de données paléoenvironnementales très précises est utilisée pour déterminer la direction du changement environnemental et comment il influence les opportunités économiques. L'étude suggère que les Inuit du Labrador profitèrent d'une sécurité économique au $18 \mathrm{e}$ siècle, aidés en partie par l'interlude d'un climat et de conditions de la glace modérés. Ces conditions encouragèrent la pratique de méthodes coopératives dans la chasse aux mammifères marins, qui furent renforcées par l'utilisation de résidences communautaires. Cette économie facilita la production de surplus et l'adoption de stratégies économiques à risque ainsi qu'un rôle social plus proéminent pour certains individus. 